\title{
PRIHODNOST USTVARJAMO LJUDJE
}
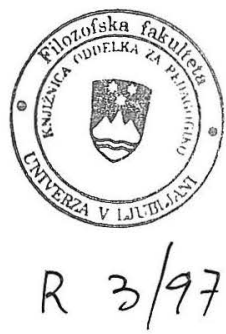

ilj vseživljenjskega učenja je usposobiti ljudi, da bodo soustvarjali takšno prihodnost, kakršno si želijo zase in za svoje otroke. Toda, ali dosedanja praksa res izpolnjuje to poslanstvo? Večinoma razmišljamo, kaj bi lahko z izobraževanjem pridobili, le redkokdaj pa pri tem pomislimo, kakšno prihodnost zares hočemo in želimo.

Mednarodna konkurenčnost, ustvarjanje informacijske družbe in zagotavljanje usposobljene delovne sile so ponavadi aktualne in resnične potrebe izobraževanja odraslih, ki jih sprejemamo molče, brez vprašanj. Prav tako sprejmemo kot neizpodbitno dejstvo spoznanje, da je poglavitni namen izobraževanja brezposelnih omogočiti brezposelnim ponovno zaposlitev in jih usposobiti, da si najdejo drugo delo. Delo v današnji družbi je največja vrednota in zdi se, da sta ji naše življenje in smisel bivanja podrejena.

Če pogledamo v zakulisje državnega financiranja, ugotovimo, da večino denarja vlagamo $v$ projekte za izboljšanje tehnologije. In kaj smo dosegli? Neskončno stresne in dolge delovne dni, zaradi katerih smo prikrajšani za nove in spodbudnejše socialne odnose. Sprijaznili smo se z okoljem, v katerem prevladuje ostro tekmovanje, in si neutrudno prizadevamo za še večjo učinkovitost, večji dobiček. Živimo v družbi, ki zmagovalce bogato nagrajuje, poražencem pa odvzema družbene in kulturne privilegije. Skladno s prevladujočo ideologijo porabniške družbe ustvarjamo čedalje popolnejše tehnologije, $\mathrm{v}$ tej luči podpiramo znanost in pospešujemo raziskave. In pri tem se nikoli prav zares ne vprašamo, ali je to prihodnost, ki si jo želimo, ali je to prihodnost, ki smo jo namenili prihodnjim generacijam?

Bilo bi v nasprotju s človeškim dostojanstvom, če bi dovolili, da se ves razvoj usmeri le v zadovoljevanje političnih in ekonomskih interesov. Ali ni že čas, da $\mathrm{v}$ informacijski družbi in družbi tekmovalnih odnosov poskrbimo za bolj humane odnose, ki bodo temeljili predvsem na prijateljskem sodelovanju, člove-

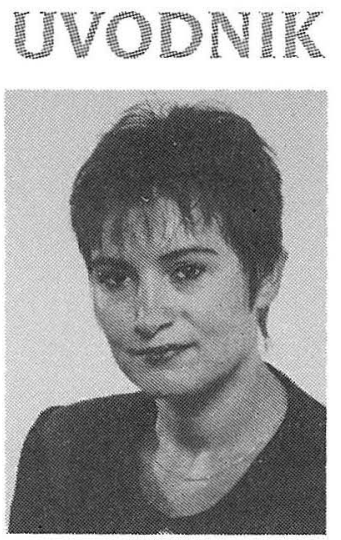

Daniela Brečko, odgovorna urednica

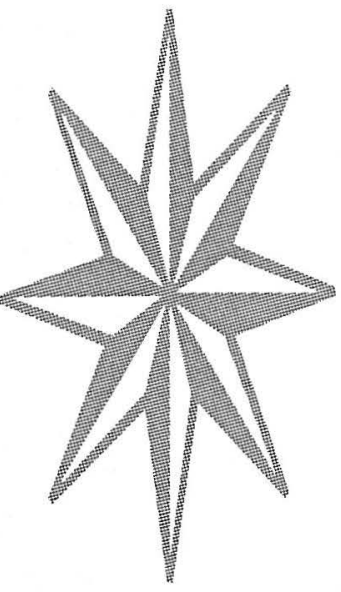

Ace 109 ku pa bodo povrnili izgubljen ugled in spoštovanje.

Pri sprejemanju pomembnih odločitev o našem poklicnem življenju bi morali večkrat pomisliti na našo prihodnost, na to, kaj želimo od nje, in na prihodnost naslednjih generacij. Stare vrednote izginjajo, a vendar še vedno poveličujemo nenehen lov za kratkoročnimi prednostmi in tako (ne)hote uničujemo možnosti za preživetje naših zanamcev.

Kaj je lahko torej cilj vseživljenjskega učenja? Ali je morda iskanje ustreznega ravnotežja med temeljnimi človeškimi in delovnimi vrednotami?

Jasno je, da izobraževanje ne more preprečiti sprejemanja napačnih odločitev politikov, gospodarstvenikov, ekonomistov. Po drugi strani pa ne smemo dovoliti, da bi bila funkcija izobraževanja odraslih le odpravljanje napak, ki smo jih storili $\mathrm{v}$ preteklosti. Izobraževanje odraslih mora razvijati tudi takšne vrednote, $\mathrm{ki}$ bodo ohranjale človekovo dostojanstvo in integriteto. Vrednote izobraževalcev in načrtovalcev izobraževanja odraslih se bodo nedvomno zrcalile tudi v kurikularni prenovi, ki prav zdaj intenzivno poteka v Sloveniji. Ali bo nam uspelo vključiti tudi vrednote, ki bodo spodbujale osebnostni razvoj odraslih?

Izobraževanje bi nam moralo med različnimi in včasih popolnoma nepričakovanimi izbirami pomagati pri sprejemanju pravilnih odločitev.

Če se strinjamo z ugotovitvijo, da naj izobraževanje omogoči ljudem lažje in prijaznejše življenje, se kaže tekmovanje med izobraževalnimi institucijami in drugimi organizacijami, ki so si za svojo nalogo naložile skrb za človeka, kot dokaj slaba strategija razvoja. Morali bi preseči ideologijo tekmovalnosti, odnosov zmagovalec-poraženec in razviti kulturo, ki bo temeljila na sodelovanju, na odnosu zmagovalec-zmagovalec. Pri tem bomo več storili za življenje samo, ne le $v$ fizičnem, temveč tudi duhovnem smislu.

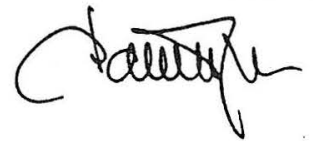

